UNDERGRADUATE RESEARCH IN NATURAL AND CLINICAL SCIENCE AND TECHNOLOGY (URNCST) JOURNAL

Read more URNCST Journal articles and submit your own today at: https://www.urncst.com

\title{
A Literature Review of the Effects of PCOS on Cardiovascular Health
}

\author{
Kshitija P. Mundle, BHSc Student [1]*, Zoha Raza, BHSc Student [1] \\ [1] School of Health Studies, University of Western Ontario, London, Ontario, Canada N6A 3K7 \\ *Corresponding Author: kmundle@uwo.ca
}

\begin{abstract}
Introduction: Polycystic ovarian syndrome (PCOS) is a common endocrine disorder found in individuals with female reproductive organs. It is known to cause excess production of androgens, which leads to a wide variety of issues, ranging from complications with bodily function and changes in physical appearance. This review will specifically focus on the relationship between PCOS and its effects on cardiovascular health to understand the long-term implications of the disorder. The variety of treatments used for PCOS and how they affect cardiovascular health will also be explored.

Methods: Research over a span of 30 years was compiled to examine the effects of PCOS on women's cardiovascular health outcomes.

Results: The findings support that there is indeed an adverse relationship between PCOS and cardiovascular health; however, treatments are available to combat these effects. PCOS has a negative influence on the health of the cardiovascular system; it increases the risk of hypertension and blood vessel/artery damage, metabolic disturbances such as diabetes, dyslipidemia, and insulin resistance, and has negative implications (undesirable effects) on hormones, such as insulin and androgen levels. There are multiple interventions ranging from oral contraception (OCP), lifestyle changes, and herbal medications that can reverse the effects of PCOS on the cardiovascular system. Due to the nature of PCOS, however, the results of the studies examined in this review are not an exact prospect for every affected individual and will require extensive research. Furthermore, more research is required to continue to understand other biological factors in this relationship, as well as looking into social determinants that may enhance or alter these results.

Conclusion: Ultimately, this review intends to promote further studies of the long-term effects of this hormonal disorder. Further research will not only improve the current treatment processes but may also benefit the conversation around this topic so that those who do struggle with PCOS can be more cognizant of its potential health outcomes.
\end{abstract}

Keywords: polycystic ovarian syndrome; hypertension; metabolic syndrome; insulin; polycystic ovarian syndrome treatments

\section{Introduction}

Polycystic ovarian syndrome (PCOS) is a common endocrine disorder found in 1 in 15 women and can be diagnosed from early adolescence to adulthood [1]. It is characterized by an imbalance of hormones in the reproductive system that leads to a plethora of different symptoms. PCOS is considered a multifactorial disorder that is still not completely understood by the medical and scientific community; however, there is evidence that points to a few probable causes. One cause is an enzymatic defect in the steroidogenesis of the ovaries and/or adrenal glands [2]. Another cause is that the gonadotropin-releasing hormone that promotes luteinizing hormone secretion is damaged [2]. A third cause, which is also explored in this review, is a change in insulin production that causes hyperinsulinemia, which leads to hyperandrogenism [2]. More recent research suggests that PCOS may be present in utero via a hostile intrauterine environment, thus allowing it to have lasting effects during the entirety of a woman's life [3]. As a result, it becomes imperative to understand the nature of PCOS and in turn to prevent further health complications that may arise from this disorder.

Furthermore, it is important to recognize the potential economic burden that results from this disorder. Research suggests that the United States alone spends 4 billion dollars each year to screen for PCOS as well as to treat the resulting symptoms such as hirsutism, infertility, and diabetes mellitus [4]; though this does not include potential cardiovascular issues. Studies show that individuals with PCOS are twice as likely to be admitted to a hospital in comparison to patients who do not have PCOS [5]. This review aims to accomplish a greater understanding of the implications of PCOS on an individual's cardiovascular health as well understanding the extent to which these effects are mitigated or changed as a result of the current interventions and treatment options available for PCOS. 
UNDERGRADUATE RESEARCH IN NATURAL AND CLINICAL SCIENCE AND TECHNOLOGY (URNCST) JOURNAL Read more URNCST Journal articles and submit your own today at: $\underline{\text { https://www.urncst.com }}$

Therefore, there is great reason to further the understanding of the diagnosis and implications of PCOS which will have profound impact on clinical and economic outcomes.

\section{Current Diagnostic Methods}

According to the Rotterdam criteria created by the European Society for Human Reproduction and Embryology and the American Society for Reproductive Medicine there exists three criteria for the presence of PCOS; at least two of the three criteria must be met to diagnose an individual with PCOS [5]. The three criteria for diagnosing PCOS include: hyperandrogenism, chronic anovulation, and the presence of cysts on the ovaries, as detailed further below [1].

First, hyperandrogenism is an endocrine disorder that entails excess production of androgens in the female reproductive system. This disorder can manifest as hirsutism, androgenic alopecia, acne, and the presence of seborrhoea [7].

Second, chronic anovulation is characterized by a lack of ovulation and skipped ovulation cycles. This is due to excessive production of androgens in the ovaries, the follicles in the reproductive system fail to respond to the normal amounts of follicle-stimulating hormone and thus cause anovulation [8]. It is believed that around $70 \%$ of anovulation and infertility issues are a result of PCOS, therefore making it appropriate criteria for diagnosis [9].

Finally, cystic ovaries is another clear marker for the presence of PCOS, often diagnosed through an ultrasound. Depending on the number and size of the cyst(s) on the ovaries, surgery may be recommended. Furthermore, when patients experience all of the three criteria of; anovulation, hyperandrogenism, and/or ovarian cysts, the diagnosis for PCOS is more strongly supported [1].

\section{Methods}

A literature review was conducted by searching for literature through Google Scholar and MEDLINE. A variety of articles dating from 2008-2020 were selected.

\section{Results}

PCOS and Cardiovascular Health

Research indicates that individuals with PCOS have an elevated risk of coronary artery disease. Several studies have found a strong relationship between the presence of PCOS and hypertension, as well as its role in developing cardiovascular issues. Hypertension has a direct effect on the coronary arteries; it can cause them to lose elasticity and constrict, which decreases the blood and oxygen flow to the heart [10]. This can lead to angina, heart attack, and in extreme cases, heart failure [10].

In a randomized control study conducted by Ding et al., the incidence rate of coronary arterial disease was $63 \%$ higher in individuals with PCOS, compared to controls [11]. After follow-up approximately 3-4 years and 5-9 years after treatment, the negative outcomes associated with coronary arterial disease remained higher in individuals with PCOS [11]. This finding is supported by a cross-sectional study completed by Marchesan et al., exploring the association between PCOS-related symptoms with systemic arterial hypertension [12]. The study included 233 individuals with PCOS and 70 controls and found more individuals with PCOS to have hypertension [12].

Another cross-sectional study conducted by the Australian Longitudinal Study on Women's Health (ALSWH) examined the prevalence of hypertension in individuals with PCOS with an added focus on the impact of obesity. This study found that young individuals with PCOS had higher body mass index and the reported prevalence of hypertension in this group was 3.5\% higher than young women who did not have PCOS [13]. Furthermore, hypertension in these women did not appear to be associated with BMI, suggesting that these issues are present in individuals with PCOS independent of higher BMIs [13]. The relationship between BMI and obesity is further discussed in the section "PCOS and Metabolic Disturbances, including Diabetes, Dyslipidemia, and Effect on Body Composition".

Another study by Cascella et al. explored aldosterone levels in individuals with PCOS, given that prior research has shown that higher aldosterone levels can serve as a marker for hypertension risk [14-15]. This study found that aldosterone levels were significantly increased in individuals with PCOS [14]. Furthermore, it concluded individuals with PCOS display insulin resistance related to the increase in aldosterone levels [14].

\section{Treatments}

Looking onwards to current treatment options, in a study by Muneyyirci-Delale et al., spironolactone was used to treat the impacts of PCOS on blood pressure, artery elasticity, and BMI [16]. After treatment, researchers reported that the systolic pressure, diastolic pressure, and BMI were the same, but there was a decrease in pulse pressure and an increase in large artery elasticity. The use of spironolactone was also supported by a study by Macut et. al in which the treatment could ameliorate endothelial dysfunction [17]. Endothelial dysfunction is characterized when a type of large blood vessels on the heart's surface constrict instead of dilating, leading to chronic chest pain. This treatment eases this constriction and increases elasticity.

The risk of hypertension and coronary arterial disease is elevated in individuals with PCOS. Aldosterone is a key chemical that is elevated in individuals with PCOS, which can lead to hypertension. To treat hypertension and the impact of PCOS on the cardiovascular system, the use of spironolactone has been supported to decrease endothelial dysfunction and increase the elasticity of large blood vessels. 
UNDERGRADUATE RESEARCH IN NATURAL AND CLINICAL SCIENCE AND TECHNOLOGY (URNCST) JOURNAL Read more URNCST Journal articles and submit your own today at: $\underline{\text { https://www.urncst.com }}$

PCOS and Metabolic Disturbances, Including Diabetes, Dyslipidemia, and Body Composition

There are also effects of PCOS on an individual's metabolic health, where it can contribute to diabetes and dyslipidemia. In a cross-sectional study by Satyaraddi et al., body composition, metabolic characteristics, and levels of insulin resistance were compared between women who were obese and had PCOS, women who were not obese and had PCOS, and a control group of women who did not have PCOS, matched by BMI to the women in the two other groups [18]. According to a visceral adipose tissue assessment conducted, it was found that individuals with PCOS had more visceral adiposity than the control group [18]. The difference between obese and non-obese individuals with PCOS was not significant. Visceral fat assessments are important to note in terms of cardiovascular health. In the context of this paper, this visceral fat build-up in the abdominal cavity caused by PCOS affects cardiovascular health by causing a build-up of plaque in the arteries. This increases the risk for cardiovascular disease.

An expert review paper conducted by Wild et al. contrasts the study by Satyaraddi et al. because there were significant differences between individuals with PCOS who were obese and individuals with PCOS who were not obese [19-18]. In this review, at various levels of BMI, individuals with PCOS were at a greater risk at cardiovascular disease than women who did not have PCOS and were at the same BMI for a wide variety of conditions; however, individuals with PCOS, who were also obese, were at a significantly higher risk than individuals with PCOS who were of normal BMI. PCOS was shown to increase the risk of impaired glucose tolerance, dyslipidemia, and metabolic syndrome.

Another study that explored the impact of PCOS on metabolic disturbances was conducted by Maffazioli et al., which investigated the prevalence of metabolic disturbances among Brazilian individuals with PCOS [20]. It was found that there was a high prevalence of insulin resistance, glucose intolerance, type 2 diabetes, dyslipidemia due to decreased HDL, hypertriglyceridemia and metabolic syndrome in the group of individuals with PCOS compared to those without PCOS. This is consistent with the findings from a study by Wang et al. that examined the effects of PCOS on long-term diabetes and dyslipidemia in white and black women in the Coronary Artery Risk Development In young Adults (CARDIA) study [21]. It was found that individuals with PCOS, regardless of BMI, had a higher chance of acquiring type 2 diabetes and dyslipidemia. The reason why insulin is a key component of PCOS is because hyperinsulinemia (elevated levels of insulin) caused by alterations in insulin action signals the ovaries to release excess androgen, leading to hyperandrogenism. This leads to increased abdominal fat gain, which in turn leads to insulin resistance and inflammation [2].
These outcomes on an individual's arteries can promote negative implications for one's cardiovascular health as it can lead to the growth of plaque in the arteries by increasing levels of low-density lipoprotein (LDL) leading to atherosclerosis and a higher chance of having a heart attack.

\section{Treatments}

A study conducted by Desai et al. explored the lipid correcting effects of Aloe Vera Gel on the lipid profile of rats with PCOS [22]. It was found that after administering an oral aloe vera gel formulation for 30 days, there was a decrease in plasma triglyceride and LDL cholesterol levels, an increase in high density lipoprotein (HDL) cholesterol, glucose tolerance, and lipid metabolizing activities, and the estrous cyclicity reverted to normal [22].

Shifting the focus from medication to lifestyle interventions, a systematic review and meta-analysis conducted by Haqq et al. looked into how dietary and exercise interventions caused favourable changes in body mass composition, rates of fertility, reduced resting heart rate, and increased rate of oxygen consumption in individuals with PCOS [23]. However, this review showed no significant differences in lipid profiles for individuals with PCOS [23]. This contrasts the study by Chandrasekaran et al., which is discussed in the following paragraph, that did find a significant difference in lipid profiles for individuals with PCOS as compared to women without PCOS [24].

In a review by Chandrasekaran et al., lifestyle adjustments and the use of multiple medical drugs were found to combat the metabolic effects of PCOS, which in turn also improve cardiovascular health [24]. Reducing body weight through exercise and dietary modifications is associated with a decrease in abdominal fat, which leads to lower insulin resistance and a more desirable lipid profile (higher HDLs and lower LDLs) [24]. In terms of medical drugs, metformin can prevent type 2 diabetes and decrease fasting insulin levels [24]. This benefit, however, was shown to only aid individuals with PCOS who were not obese. Further research is needed to determine whether or not metformin had similar effects on women that were obese. Another drug that is beneficial is inositol, which is shown to decrease excess insulin levels, improve the lipid profile and reduce systolic blood pressure [24]. Orlistat, an anti-obesity drug, is also used for women who are obese and with PCOS. It prevents the breakdown and absorption of dietary fats and leads to reductions in the levels of total cholesterol, low-density lipoprotein and triglycerides, as well as decreased insulin resistance and risk for type 2 diabetes [24]. Liraglutide was also mentioned as an antiobesity agent; however, it did not show significant reductions in waist/hip ratio which is important in determining the effects of abdominal fat, and it did not show any effects on resting insulin levels or insulin resistance [24]. Statins were also mentioned to aid in 
UNDERGRADUATE RESEARCH IN NATURAL AND CLINICAL SCIENCE AND TECHNOLOGY (URNCST) JOURNAL Read more URNCST Journal articles and submit your own today at: https://www.urncst.com

dyslipidemia caused by PCOS to significantly improve lipid profiles [24].

Individuals that have PCOS are at a greater risk of developing metabolic disturbances such as diabetes, insulin resistance, glucose intolerance, dyslipidemia, and metabolic syndrome than people who do not have PCOS. Articles had conflicting views on whether being obese and with PCOS puts one at greater risk of developing these conditions. The study by Satyaraddi et al. found that there was not a significant difference in risk for metabolic disturbances between individuals with PCOS and varying BMIs, but the studies by Wild et al. and Joham et al. found that there was a significant difference between women who had PCOS that were obese and women who had PCOS that were not obese; women who were obese and with PCOS were at greater risk [19, 13, 18]. These metabolic syndromes lead to higher amounts of abdominal fat, which can affect the coronary arteries by causing a build-up of plaque. In terms of treatment, multiple drugs, lifestyle interventions, and herbal medications have been associated with lowering the risk of metabolic disturbances, which in turn also helps to ameliorate poor cardiovascular health. Aloe Vera Gel has shown to be effective in affecting desirable lipid profile levels and estrous cyclicity levels, and improve glucose tolerance. Lifestyle changes have been supported to be very impactful in metabolic disturbances, as well, such as exercise and dietary modifications. Medical drugs such as metformin and inositol helped to lower insulin levels and create more desirable lipid profiles. Anti-obesity agents, such as orlistat, are aimed towards women who are obese and with PCOS, and aid in reducing body weight and visceral fat, which have negative impacts on the cardiovascular system. Statins are also used to improve lipid profiles caused by dyslipidemia.

\section{PCOS and Hormones}

One cross-sectional study conducted on the Greek Island of Lesbos focused on the prevalence of PCOS in the Greek population as well as looking into the hormonal and metabolic parameters, and any potential correlations of the two. They found that the severity of the clinical phenotype (physical manifestations) was impacted by the severity of the hyperinsulinemia of the patient [25]. Hyperinsulinemia leads to hyperandrogenism, which is a key marker of PCOS.

\section{Treatments}

Multiple treatments target the hormonal issues caused by PCOS. These hormonal fluctuations can have an impact on cardiovascular health, as previously discussed. In a randomized control trial by Shah et al., the effects of oral contraception and lifestyle modifications on hormones related to PCOS were explored [26]. Incretins and (transforming growth factors) TGF-s superfamily were studied. A lack of incretins results in an increase of blood glucose levels, and an increase of TGF-s superfamily, which is expressed in the ovary, has been linked to causing the pathogenesis of abnormal follicle development and hyperandrogenism. The lifestyle group was treated with a $500 \mathrm{kcal} / \mathrm{d}$ deficit diet, encouraged to increase physical activity, and received behavioural modification counselling regarding healthy eating and nutrition. The oral contraception group was treated with a continuous daily dose of $20 \mathrm{mcg}$ ethinyl estradiol and $1 \mathrm{mg}$ norethindrone acetate. A third group was subject to both treatments. It was found that the oral contraception group had significant changes in hormonal levels, while in comparison the combined group had minimal changes, and the lifestyle group had no changes. The results of this study show an increase in incretin levels and a decrease in TGF-s superfamily levels, indicating how OCPs are more effective in the treatment of PCOS than lifestyle modification. The findings of this study concerning lifestyle are inconsistent with the study by Haqq et al. in which lifestyle interventions were supported in increasing cardiorespiratory fitness and glycemic control and improving body composition [23]. However, more research is still required to understand the reasons as to why lifestyle as an intervention does not always support significant hormonal changes in individuals with PCOS [23].

Further discussing the topic of oral medicine, a study by Prabhakar et al. examined the effects of myoinositol plus metformin as compared to myoinositol alone on individuals with PCOS who were infertile and going through ovulation induction cycles [27]. Metformin is commonly used to treat type 2 diabetes. The subjects in this study were advised to try for spontaneous conception, which is the birth of a child, after the birth of a child conceived through assisted reproductive technology. After 6 months, the clinical pregnancy rate was $42.0 \%$ in the group using myoinositol and metformin and $45.5 \%$ in the group using myoinositol. Thus, myoinositol can be used alone as an insulin sensitizer to improve metabolic, hormonal and reproductive outcomes for individuals with PCOS who are infertile. By targeting insulin resistance, myoinositol improves metabolic and hormonal outcomes by improving the hormonal profile, oxidative abnormalities and metabolic factors of individuals with PCOS. These metabolic and hormonal parameters included improvements in BMI, waist-hip ratio, LH-FSH ratio, $\mathrm{AMH}$ levels, and lipid profiles. Another review by Genazanni et al. summarized literature regarding the use of inositols, specifically myo-inositol and d-chiro-inositol, in the treatment for PCOS patients [28]. PCOS patients usually have higher plasma concentrations of ovarian and adrenal androgens. This review especially examined hyperinsulinemia on top of the usual insulin resistance that was widely discussed in previous articles. The review concluded that inositol could widely be used to treat abnormal glucose and insulin levels by stimulating insulin hormone signalling.

Another clinical study administered nafarelin to compare the unique responses that may arise from an 
UNDERGRADUATE RESEARCH IN NATURAL AND CLINICAL SCIENCE AND TECHNOLOGY (URNCST) JOURNAL Read more URNCST Journal articles and submit your own today at: https://www.urncst.com

individual with PCOS. Nafarelin is a gonadotropin releasing-hormone agonist used to secrete gonadal and stimulate the pituitary gland [29]. The study consisted of 16 healthy women with no signs of PCOS, 5 men, 8 individuals with PCOS, and 1 woman with PCOS caused by a $3 \beta$-hydroxysteroid dehydrogenase deficiency [29]. The study found that after the administration of the nafarelin, the individuals with PCOS had a similar hormonal response pattern as men which was seen through increased production of $17 \alpha$-hydroxyprogesterone in both groups [29]. The research concluded that individuals with PCOS had a "masculinized pituitary and ovarian responses" from stimulation from nafarelin [29]. This study demonstrates the abnormal hormonal reactions from individuals with PCOS indicating its effects on the endocrine system.

Shifting the focus towards a potential herbal treatment method, in a randomized control study by Rababa'h et al, the effects of the marjoram plant on the hormonal effects of PCOS was studied [30]. There were five randomly assigned groups, which included a control group, a dehydroepiandrosterone induced-PCOS model group, a marjoram-treated PCOS group, a metformin-treated PCOS group and a PCOS group treated with a combination of marjoram and metformin [30]. It was found that marjoram administration on DHEA-induced PCOS was most beneficial. There was an improvement in hormonal levels, there was a reduction in ovarian weight, increased insulin sensitivity, increased antioxidants, and increased antiinflammatory parameters [30].

PCOS has a major hormonal effect which in turn can damage cardiovascular health. Hyperinsulinemia leads to hyperandrogenism, causing insulin resistance and inflammation, which can negatively impact coronary arteries by causing a build-up of plaque. Multiple treatments target the effect of PCOS on hormones. Lifestyle modifications were shown to affect metabolic disturbances, but not directly on the hormones that cause PCOS, so oral medications are more widely used to treat PCOS. Myoinositol and metformin were more chemicals that helped to reduce hyperinsulinemia, which is a widely supported cause for PCOS. Nafarelin is also another treatment that could be used for hormones released by PCOS because it regulates the release of GnRH. Marjoram plants have also been shown to decrease the hormonal effects of PCOS.

\section{Conclusion}

This literature review summarized research examining the negative effects of PCOS on cardiovascular health and underlying metabolic and hormonal regulation. This implies higher risk for developing cardiovascular disease in individuals who suffer from PCOS. However, multiple treatments can help to reverse these effects.

The results suggest that PCOS has a variety of impacts on cardiovascular health; however, there are several treatments that can ameliorate the effects of PCOS and rebuild cardiovascular wellbeing.

Furthermore, the literature lacks clinical trials and further studies on women with obesity and PCOS as well as further research in women with high levels of visceral fat and the impact of treatment options. In the future research can be directed towards the longer term impacts of treatments on individuals cardiovascular health outcomes instead of focusing on only the effects of the treatment on PCOS itself. Research can look into questions of whether individuals with PCOS should prefer certain treatment options over others in pursuit of better cardiovascular health.

Overall, there is still much that is needed to be known about the impacts of PCOS and treatment options to offer the proper preventative methods.

Table 1. Summary of the Effects of PCOS on Cardiovascular Outcomes

\begin{tabular}{|l|l|}
\hline PCOS and Bodily & Cardiovascular Outcome \\
\hline $\begin{array}{l}\text { PCOS and Cardiovascular } \\
\text { Health }\end{array}$ & $\bullet \begin{array}{l}\text { PCOS increases the risk of coronary artery disease and hypertension, leading to loss of } \\
\text { elasticity in blood vessels and increased constriction, which decreases blood flow to the } \\
\text { heart, and may lead to angina, heart attack, and/or heart failure [10-12]. }\end{array}$ \\
$\begin{array}{l}\text { Individuals with PCOS, who are also obese have a greater risk of hypertension and } \\
\text { insulin resistance than individuals with PCOS who are not obese [13-15]. Both groups } \\
\text { of individuals have a higher risk of hypertension than individuals without PCOS or } \\
\text { obesity [14]. }\end{array}$ \\
\hline $\begin{array}{l}\text { PCOS and Metabolic } \\
\text { Disturbances, including } \\
\text { Body Composition }\end{array}$ & $\begin{array}{l}\text { The difference in levels of insulin resistance and visceral adipose tissue between } \\
\text { individuals with PCOS who are obese and individuals with PCOS who are not obese, was } \\
\text { statistically significant in the study conducted by Wild et al. with individuals with obesity } \\
\text { having greater risk for both [19]. This was found to be not statistically significant in the } \\
\text { study by Satyaraddi et al. with both groups of individuals having similar levels of insulin } \\
\text { resistance and visceral adipose tissue [18]. In both studies, both groups of individuals }\end{array}$ \\
\hline
\end{tabular}


UNDERGRADUATE RESEARCH IN NATURAL AND CLINICAL SCIENCE AND TECHNOLOGY (URNCST) JOURNAL Read more URNCST Journal articles and submit your own today at: https://www.urncst.com

\begin{tabular}{|l|l|}
\hline $\begin{array}{l}\text { PCOS and Bodily } \\
\text { System/Function }\end{array}$ & $\underline{\text { Cardiovascular Outcome }}$ \\
\hline & $\begin{array}{l}\text { with PCOS have greater levels of insulin resistance and visceral adipose tissue than } \\
\text { individuals without PCOS [18-19]. Visceral fat build up affects cardiovascular health by } \\
\text { causing a build-up of plaque in the arteries [18]. } \\
\text { PCOS increases the risk of impaired glucose tolerance, insulin resistance, type 2 } \\
\text { diabetes, dyslipidemia (due to increased HDL and hyperinsulinemia), and metabolic } \\
\text { syndrome [18-20]. }\end{array}$ \\
$\qquad \begin{array}{l}\text { The aforementioned metabolic disturbances increase low-density lipoprotein (LDL) } \\
\text { leading to atherosclerosis and a higher chance of having a heart attack [20]. }\end{array}$ \\
\hline PCOS and Hormones & $\begin{array}{l}\text { PCOS is caused by alterations in insulin action that signals the ovaries to release excess } \\
\text { androgen, leading to hyperandrogenism. This leads to increased abdominal fat gain, } \\
\text { which in turn leads to insulin resistance and inflammation [20]. }\end{array}$ \\
\hline
\end{tabular}

Table 2. Summary of the Effects of PCOS Treatment on Cardiovascular Outcomes

\begin{tabular}{|c|c|c|c|}
\hline$\frac{\text { PCOS and Bodily }}{\text { System/Function }}$ & $\begin{array}{l}\text { Treatment } \\
\text { Options }\end{array}$ & Effects of Treatment & Limits \\
\hline $\begin{array}{l}\text { PCOS and } \\
\text { Cardiovascular } \\
\text { Health }\end{array}$ & - Spironolactone & $\begin{array}{l}\text { - Systolic pressure, diastolic pressure, and BMI } \\
\text { remained the same } \\
\text { - There was a decrease in pulse pressure and an } \\
\text { increase in large artery elasticity. [16] } \\
\text { - Can ameliorate endothelial dysfunction [17] } \\
\text { - Decrease effects of hypertension }\end{array}$ & \\
\hline \multirow[t]{2}{*}{$\begin{array}{l}\text { PCOS and } \\
\text { Metabolic } \\
\text { Disturbances, } \\
\text { including Diabetes, } \\
\text { Dyslipidemia, and } \\
\text { Body Composition }\end{array}$} & - Aloe vera gel & $\begin{array}{l}\text { - After administering an oral aloe vera gel } \\
\text { formulation for } 30 \text { days (in rats) there was: } \\
\circ \text { Decrease in plasma triglyceride } \\
\circ \text { Decrease in LDL cholesterol levels } \\
\circ \text { Increase in high density lipoprotein (HDL) } \\
\text { cholesterol } \\
\circ \text { Increase in glucose tolerance } \\
\circ \text { Increase in lipid metabolizing activities, } \\
\circ \text { The estrous cyclicity reverted to normal [22] }\end{array}$ & $\begin{array}{l}\text { - Study was conducted } \\
\text { in rats [22] }\end{array}$ \\
\hline & $\begin{array}{l}\text { Dietary and } \\
\text { exercise } \\
\text { interventions }\end{array}$ & $\begin{array}{l}\text { - Favourable changes were seen in: } \\
\circ \text { Body mass composition } \\
\circ \text { Rates of fertility } \\
\circ \text { Reduced resting heart rate } \\
\circ \text { Increased rate of oxygen consumption [23] } \\
\text { - Reducing body weight through exercise and } \\
\text { dietary modifications is associated with: } \\
\circ \text { Decrease in abdominal fat } \\
\circ \text { Lower insulin resistance } \\
\circ \text { Improved lipid profile (higher HDLs and } \\
\text { lower LDLs) [24] }\end{array}$ & $\begin{array}{l}\text { - Study showed no } \\
\text { significant differences } \\
\text { in lipid profiles for } \\
\text { individuals with } \\
\text { PCOS [23] }\end{array}$ \\
\hline
\end{tabular}


UNDERGRADUATE RESEARCH IN NATURAL AND CLINICAL SCIENCE AND TECHNOLOGY (URNCST) JOURNAL Read more URNCST Journal articles and submit your own today at: https://www.urncst.com

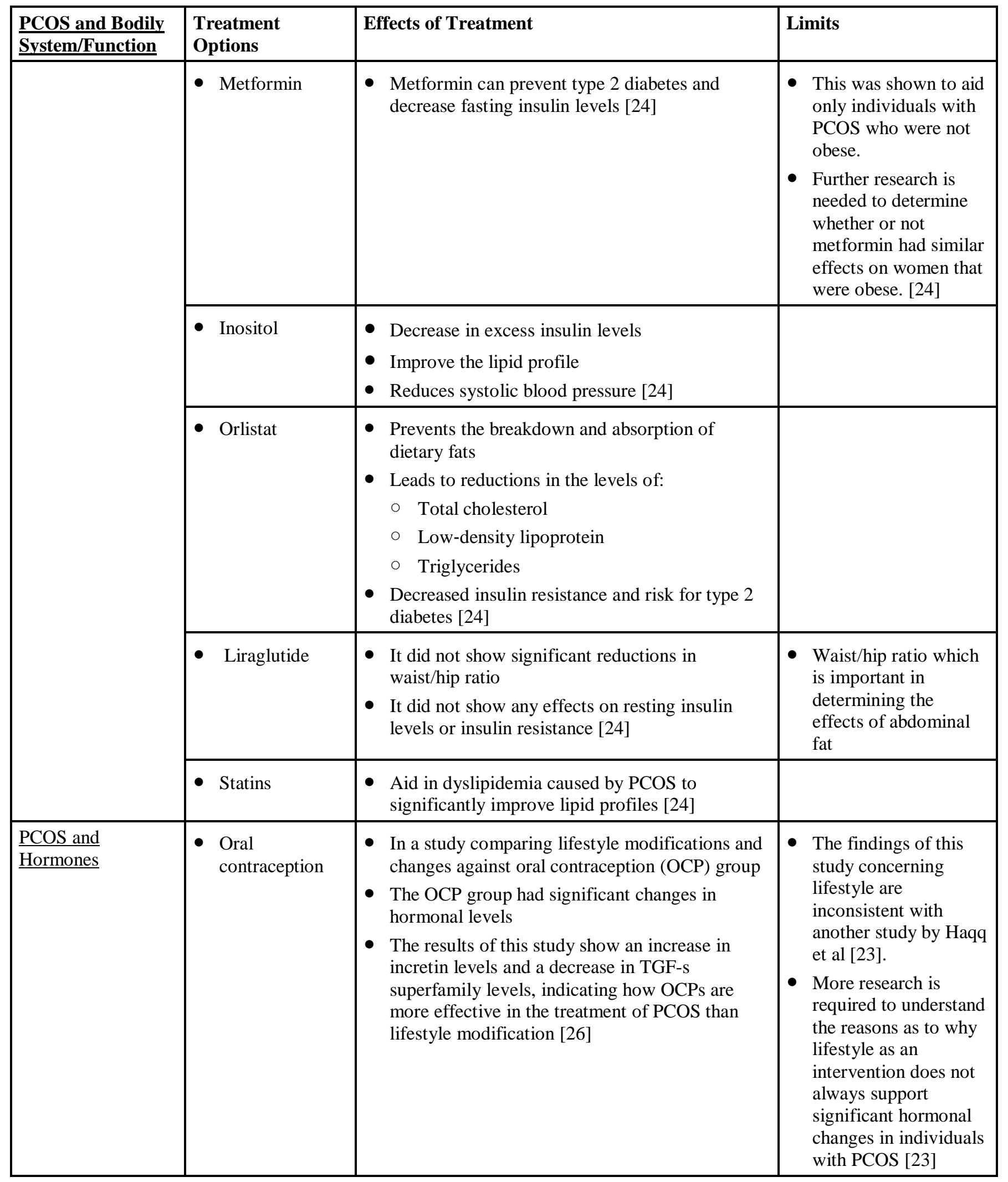


UNDERGRADUATE RESEARCH IN NATURAL AND CLINICAL SCIENCE AND TECHNOLOGY (URNCST) JOURNAL Read more URNCST Journal articles and submit your own today at: https://www.urncst.com

\begin{tabular}{|c|c|c|c|}
\hline $\begin{array}{l}\text { PCOS and Bodily } \\
\text { System/Function }\end{array}$ & $\begin{array}{l}\text { Treatment } \\
\text { Options }\end{array}$ & Effects of Treatment & Limits \\
\hline & $\begin{array}{l}\text { Metformin, } \\
\text { inositol, and } \\
\text { myoinositol }\end{array}$ & $\begin{array}{l}\text { Subjects in this study were advised to try for } \\
\text { spontaneous conception } \\
\text { - After } 6 \text { months, the clinical pregnancy rate was } \\
42.0 \% \text { in the group using myoinositol and } \\
\text { metformin and } 45.5 \% \text { in the group using } \\
\text { myoinositol only } \\
\text { - Thus, myoinositol can be used alone as an } \\
\text { insulin sensitizer to improve metabolic, } \\
\text { hormonal and reproductive outcomes for } \\
\text { individuals with PCOS who are infertile [27] } \\
\text { - Inositol could widely be used to treat abnormal } \\
\text { glucose and insulin levels by stimulating insulin } \\
\text { hormone signalling [28]. }\end{array}$ & \\
\hline & - Nafarelin & $\begin{array}{l}\text { - Could be used for hormones released by PCOS } \\
\text { because it regulates the release of GnRH. [29] }\end{array}$ & \\
\hline & 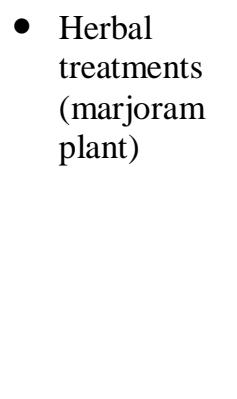 & $\begin{array}{l}\text { - It was found that marjoram administration on } \\
\text { DHEA-induced PCOS was beneficial. } \\
\text { Findings showed: } \\
\circ \text { An improvement in hormonal levels } \\
\circ \text { Reduction in ovarian weight } \\
\circ \text { Increased insulin sensitivity } \\
\circ \text { Increased antioxidants } \\
\circ \text { Increased anti-inflammatory parameters [30] }\end{array}$ & \\
\hline
\end{tabular}

List of Abbreviations Used

PCOS: polycystic ovarian syndrome

LDL: low density lipoprotein

HDL: high density lipoprotein

TGF: transforming growth factor

BMI: body mass index

OCP: oral contraceptive

LH: luteinizing hormone

FSH: follicle-stimulating hormone

AMH: Anti-Müllerian hormone

\section{Conflicts of Interest}

The author(s) declared no potential conflicts of interest with respect to the research, authorship, and/or publication of this article.

Ethics Approval and/or Participant Consent Ethics Approval did not need to be obtained.

Authors' Contributions

KPM and ZR wrote the manuscript and reviewed the final manuscript.

\section{Acknowledgements}

We thank Jennifer Williams (McMaster University, Canada) for being a mentor in this process.

\section{Funding}

The author(s) received no financial support for the research, authorship, and/or publication of this article.

\section{References}

[1] Norman RJ, Dewailly D, Legro RS, Hickey TE. Polycystic ovary syndrome. The Lancet. 2007 Aug 25;370(9588):685-97. https://doi.org/10.1016/S01406736(07)61345-2

[2] Baptiste CG, Battista MC, Trottier A, Baillargeon JP. Insulin and hyperandrogenism in women with polycystic ovary syndrome. The Journal of steroid biochemistry and molecular biology. 2010 Oct 1;122(1-3):42-52. https://doi.org/10.1016/j.jsbmb.2009.12.010

[3] Franks S, McCarthy MI, Hardy K. Development of polycystic ovary syndrome: involvement of genetic and environmental factors. International journal of andrology. 2006 Feb;29(1):278-85. https://doi.org/10.1111/j.1365-2605.2005.00623.x 
UNDERGRADUATE RESEARCH IN NATURAL AND CLINICAL SCIENCE AND TECHNOLOGY (URNCST) JOURNAL Read more URNCST Journal articles and submit your own today at: https://www.urncst.com

[4] Azziz R, Woods KS, Reyna R, Key TJ, Knochenhauer ES, Yildiz BO. The prevalence and features of the polycystic ovary syndrome in an unselected population. The Journal of Clinical Endocrinology \& Metabolism. 2004 Jun $1 ; 89(6): 2745-9$. https://doi.org/10.1210/jc.2003-032046

[5] Hart R, Doherty DA. The potential implications of a PCOS diagnosis on a woman's long-term health using data linkage. The Journal of Clinical Endocrinology \& Metabolism. 2015 Mar 1;100(3):911-9. https://doi.org/10.1210/jc.2014-3886

[6] Broekmans FJ, Knauff EA, Valkenburg O, Laven JS, Eijkemans MJ, Fauser BC. PCOS according to the Rotterdam consensus criteria: Change in prevalence among WHO-II anovulation and association with metabolic factors. BJOG. 2006 Oct;113(10):1210-7. https://doi.org/10.1111/j.1471-0528.2006.01008.x

[7] De Leo V, Musacchio MC, Cappelli V, Massaro MG, Morgante G, Petraglia F. Genetic, hormonal and metabolic aspects of PCOS: an update. Reproductive Biology and Endocrinology. 2016 Dec;14(1):1-7. https://doi.org/10.1186/s12958-016-0173-x

[8] Jonard S, Dewailly D. The follicular excess in polycystic ovaries, due to intra- ovarian hyperandrogenism, may be the main culprit for the follicular arrest. Human reproduction update. 2004 Mar 1;10(2):107-17. https://doi.org/10.1093/humupd/dmh010

[9] Sam S, Dunaif A. Polycystic ovary syndrome: syndrome XX?. Trends in Endocrinology \& Metabolism. 2003 Oct 1;14(8):365-70. https://doi.org/ 10.1016/j.tem.2003.08.002

[10] Whelton PK, Carey RM, Aronow WS, Casey DE, Collins KJ, Dennison Himmelfarb C, DePalma SM, Gidding S, Jamerson KA, Jones DW, MacLaughlin EJ. 2017ACC/AHA/AAPA/ABC/ACPM/AGS/APhA/ASH /ASPC/NMA/PCNA guideline for the prevention, detection, evaluation, and management of high blood pressure in adults: a report of the American College of Cardiology/American Heart Association Task Force on Clinical Practice Guidelines. Journal of the American College of Cardiology. 2018 May 15;71(19):e127-248. https://www.jacc.org/doi/full/10.1016/j.jacc.2017.11.0 $\underline{06}$

[11] Ding DC, Tsai IJ, Wang JH, Lin SZ, Sung FC. Coronary artery disease risk in young women with polycystic ovary syndrome. Oncotarget. 2018 Feb 2;9(9):8756. https://dx.doi.org/10.18632\%2Foncotarget.23985

[12] Marchesan LB, Spritzer PM. ACC/AHA 2017 definition of high blood pressure: implications for women with polycystic ovary syndrome. Fertility and sterility. 2019 Mar 1;111(3):579-87. https://doi.org/10.1016/j.fertnstert.2018.11.034

[13] Joham AE, Boyle JA, Zoungas S, Teede HJ. Hypertension in reproductive-aged women with polycystic ovary syndrome and association with obesity. American journal of hypertension. $2015 \mathrm{Jul}$ 1;28(7):847-51. https://doi.org/10.1093/ajh/hpu251

[14] Cascella T, Palomba S, Tauchmanovà L, Manguso F, Di Biase S, Labella D, Giallauria F, Vigorito C, Colao A, Lombardi G, Orio F. Serum aldosterone concentration and cardiovascular risk in women with polycystic ovarian syndrome. The Journal of Clinical Endocrinology \& Metabolism. 2006 Nov 1;91(11):4395-400. https://doi.org/10.1210/jc.20060399

[15] Xanthakis V, Vasan RS. Aldosterone and the risk of hypertension. Current hypertension reports. 2013 Apr 1;15(2):102-7. https://doi.org/10.1007/s11906-0130330-y

[16] Muneyyirci- Delale O, Co S, Winer N. Vascular compliance in women with polycystic ovary syndrome treated with spironolactone. The Journal of Clinical Hypertension. 2018 Oct;20(10):1536-40.

https://doi.org/10.1111/jch.13385

[17] Macut D, Mladenović V, Bjekić-Macut J, Livadas S, Stanojlović O, Hrnčić D, Rašić-Marković A, Milutinović DV, Andrić Z. Hypertension in polycystic ovary syndrome: Novel insights. Current hypertension reviews. 2020 Apr 1;16(1):55-60. https://doi.org/ $\underline{10.2174 / 1573402115666190531071422}$

[18] Satyaraddi A, Cherian KE, Kapoor N, Kunjummen AT, Kamath MS, Thomas N, Paul TV. Body composition, metabolic characteristics, and insulin resistance in obese and nonobese women with polycystic ovary syndrome. Journal of human reproductive sciences. 2019 Apr;12(2):78. https://dx.doi.org/10.4103\%2Fjhrs.JHRS 2 19

[19] Wild RA, Carmina E, Diamanti-Kandarakis E, Dokras A, Escobar-Morreale HF, Futterweit W, Lobo R, Norman RJ, Talbott E, Dumesic DA. Assessment of cardiovascular risk and prevention of cardiovascular disease in women with the polycystic ovary syndrome: a consensus statement by the Androgen Excess and Polycystic Ovary Syndrome (AE-PCOS) Society. The Journal of Clinical Endocrinology \& Metabolism. 2010 May 1;95(5):2038-49.https://doi.org/10.1210/jc.2009$\underline{2724}$

[20] Maffazioli GD, Lopes CP, Heinrich- Oliveira V, Lobo RA, Hayashida SA, Soares Jr JM, Maciel GA, Baracat EC. Prevalence of metabolic disturbances among women with polycystic ovary syndrome in different regions of Brazil. International Journal of Gynecology \& Obstetrics. 2020 Dec;151(3):383-91. https://doi.org/10.1002/ijgo.13374

[21] Wang ET, Calderon-Margalit R, Cedars MI, Daviglus ML, Merkin SS, Schreiner PJ, Sternfeld B, Wellons M, Schwartz SM, Lewis CE, Williams OD. Polycystic ovary syndrome and risk for long-term diabetes and dyslipidemia. Obstetrics and gynecology. 2011 Jan;117(1):6. 
UNDERGRADUATE RESEARCH IN NATURAL AND CLINICAL SCIENCE AND TECHNOLOGY (URNCST) JOURNAL Read more URNCST Journal articles and submit your own today at: https://www.urncst.com

https://dx.doi.org/10.1097\%2FAOG.0b013e31820209b $\underline{b}$

[22] Desai BN, Maharjan RH, Nampoothiri LP. Aloe barbadensis Mill. formulation restores lipid profile to normal in a letrozole-induced polycystic ovarian syndrome rat model. Pharmacognosy research. 2012 Apr;4(2):109. https://dx.doi.org/10.4103\%2F0974$\underline{8490.94736}$

[23] Haqq L, McFarlane J, Dieberg G, Smart N. The effect of lifestyle intervention on body composition, glycemic control, and cardiorespiratory fitness in polycystic ovarian syndrome: a systematic review and metaanalysis. International journal of sport nutrition and exercise metabolism. 2015 Dec 1;25(6):533-40.. https://doi.org/10.1123/ijsnem.2013-0232

[24] Chandrasekaran S, Sagili H. Metabolic syndrome in women with polycystic ovary syndrome. The Obstetrician \& Gynaecologist. 2018 Oct;20(4):245-52. https://doi.org/10.1111/tog.12519

[25] Diamanti-Kandarakis E, Kouli CR, Bergiele AT, Filandra FA, Tsianateli TC, Spina GG, Zapanti ED, Bartzis MI. A survey of the polycystic ovary syndrome in the Greek island of Lesbos: hormonal and metabolic profile. The journal of clinical endocrinology \& metabolism. 1999 Nov 1;84(11):4006-11. https://doi.org/10.1210/jcem.84.11.6148

[26] Shah A, Dodson WC, Kris-Etherton PM, Kunselman AR, Stetter CM, Gnatuk CL, Estes SJ, Allison KC, Sarwer DB, Sluss PM, Coutifaris C. Effects of Oral
Contraception and Lifestyle Modification on Incretins and TGF- 3 Superfamily Hormones in PCOS. The Journal of Clinical Endocrinology \& Metabolism. 2021 Jan;106(1):108-19. https://doi.org/10.1210/clinem/ dgaa682

[27] Prabhakar P, Mahey R, Gupta M, Khadgawat R, Kachhawa G, Sharma JB, Vanamail P, Kumari R, Bhatla N. Impact of myoinositol with metformin and myoinositol alone in infertile PCOS women undergoing ovulation induction cycles-randomized controlled trial. Gynecological Endocrinology. 2020 Sep 16:1-5. https://doi.org/10.1080/09513590.2020.1810657

[28] Genazzani AD. Inositol as putative integrative treatment for PCOS. Reproductive biomedicine online. 2016 Dec 1;33(6):770-80. https://doi.org/ 10.1016/j.rbmo.2016.08.024

[29] Ehrmann DA, Barnes RB, Rosenfield RL, Cavaghan MK, Imperial J. Prevalence of impaired glucose tolerance and diabetes in women with polycystic ovary syndrome. Diabetes care. 1999 Jan 1;22(1):141-6.. https://doi.org/10.2337/diacare.22.1.141

[30] Rababa'h AM, Matani BR, Ababneh MA. The ameliorative effects of marjoram in dehydroepiandrosterone induced polycystic ovary syndrome in rats. Life Sciences. 2020 Nov 15;261:118353. $\underline{\text { https://doi.org/10.1016/j.lfs.2020.118353 }}$

\section{Article Information}

Managing Editor: Jeremy Y. Ng

Peer Reviewers: Jennifer Williams, O'Llenecia Walker

Article Dates: Received Dec 31 20; Accepted Mar 03 21; Published Apr 2821

\section{Citation}

Please cite this article as follows:

Mundle KP, Raza Z. A literature review of the effects of PCOS on cardiovascular health. URNCST Journal. 2021 Apr 28:

5(4). https://urncst.com/index.php/urncst/article/view/238

DOI Link: https://doi.org/10.26685/urncst.238

\section{Copyright}

(C) Kshitija P. Mundle, Zoha Raza. (2021). Published first in the Undergraduate Research in Natural and Clinical Science and Technology (URNCST) Journal. This is an open access article distributed under the terms of the Creative Commons Attribution License (https://creativecommons.org/licenses/by/4.0/), which permits unrestricted use, distribution, and reproduction in any medium, provided the original work, first published in the Undergraduate Research in Natural and Clinical Science and Technology (URNCST) Journal, is properly cited. The complete bibliographic information, a link to the original publication on http://www.urncst.com, as well as this copyright and license information must be included. 


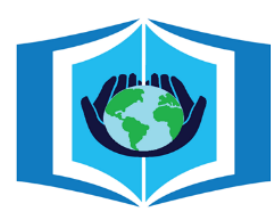

\section{URNCST Journal \\ "Research in Earnest"}

\section{Funded by the \\ Government of Canada}

\section{Canadà̀}

Do you research in earnest? Submit your next undergraduate research article to the URNCST Journal!

| Open Access | Peer-Reviewed | Rapid Turnaround Time | International | | Broad and Multidisciplinary | Indexed | Innovative | Social Media Promoted |

Pre-submission inquiries? Send us an email at info@urncst.com | Facebook, Twitter and LinkedIn: @URNCST Submit YOUR manuscript today at https://www.urncst.com! 